\title{
СИНАРОМ МАЛЬАБСОРБЦІї У ХВОРИХ, ЯКИМ НАКЛАДЕНО СТОМУ
}

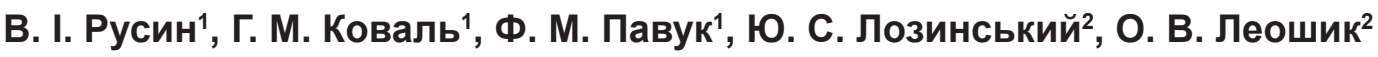 \\ ${ }^{1}$ Ужгородський національний університет, \\ 2Львівський національний медичний університет імені Данила Галицького
}

\section{SYNDROM OF MALABSORPTION IN STOMATED PATIENTS}

\author{
V. I. Rusyn'1, G. M. Kovahl', F. M. Pavuk¹, Yu. S. Lozynskyi², O. V. Leoshyk ${ }^{2}$ \\ 'Uzhgorod National University, \\ ${ }^{2}$ Lviv National Medical University named after Danylo Galytskyi
}

\begin{abstract}
Рефрерат
Проведені мікробіологічне дослідження та аналіз копрограм у 29 хворих, яким накладено стому. Залежно від рівня (локалізації) стоми хворі розподілені на 3 групи: I група - 7 хворих, у яких ілеостома накладена з приводу запальних захворювань кишечнику, зокрема, неспецифічного виразкового коліту (НВК), хвороби Крона (ХК); II група - 9 хворих, у яких сформовано асцендоколостому (у 2 - цекостому, у 7 - стому на рівні правого згину товстої кишки); III група - 13 хворих, у яких накладено десцендоколостому. Хворі II і III груп оперовані з приводу обструктивного раку, гострої непрохідності кишечнику. Встановлено, що синдром мальабсорбції найбільш виражений після ілеостомії, найменш виражений - після десцендоколостомії. В усіх хворих діагностований дисбаланс мікрофрлори з збільшенням коцентрації клостридій та умовно патогенних мікроорганізмів.

Ключові слова: колостома; мальабсорбція; мікрофлора.

\section{Abstract}

Microbial investigations and analysis of coprogrammes was done in 29 patients, to whom stoma was formatted. Depending on level (localization) of stoma, the patients were divided on 3 groups: group I - 7 patients, in whom ileostomy was done for inflammatory intestinal diseases, including, nonspeciphic ulcer colitis, Crohn disease; group II - 9 patients, in whom ascendocolostomy was formatted (in 2 coecostomy, in 7 - stomy on level of hepatic colonic flexura); group III - in 13 patients descendocolostomy was performed. The patients of group II and group III were operated for obstructive cancer, and acute ileus. There was established, that malabsorption syndrome is mostly expressed after ileostomy, the least expressed - after descendocolostomy. In all the patients the microflora misbalance was diagnosed with enhancement of the clostridia and conditionally pathogenetic microorganisms concentration.

Keywords: colostoma; malabsorption; microflora.
\end{abstract}

Будь-яка операція на травному каналі (ТК) з виведенням стоми пов'язана 3 появою в подальшому тяжких патофізіологічних процесів, що реалізуються як порушення травлення й всмоктування їжі - синдром мальабсорбції. За даними експериментальних досліджень і клінічних спостережень, найбільших змін зазнає абсорбція жирів. Виражену стеаторею спостерігають у більшості хворих у різні строки після оперативного втручання. В перші місяці засвоювання жиру зменшується на 60 - 70\%, в нормі - 90 - 95\%. У подальшому засвоювання жиру може покращуватись, проте, на думку більшості авторів, ніколи не досягає норми [1]. Основною причиною цього є неадекватне змішування їжі з жовчю і панкреатичним соком внаслідок втрати моторно-евакуаторної функції КТ, через зменшення довжини кишечнику. При збільшенні кількості жирів у дієті збільшується їх кількість в калових масах $[2,3]$. Постійне й нерегульоване від- ходження вмісту кишечнику, складності догляду за стомою та деякі інші обставини повністю виключають хворих з суспільного, а іноді й сімейного життя [4].

Актуальним $€$ проведення мікробіологічних досліджень стомованих ділянок тонкої та товстої кишки для вибору адекватних методів профілактики гнійно-септичних ускладнень, а також планування реконструктивно-відновних операцій.

\section{МАТЕРІАЛИ І МЕТОДИ ДОСЛІДЖЕННЯ}

Проведений аналіз копрограм у 29 хворих, в тому числі 12 жінок та 17 чоловіків, віком від 23 до 69 років. Залежно від рівня колостоми хвоpi розподілені на 3 групи: I група 7 хворих, у яких накладено ілеостому (4 - оперовані з приводу ускладненого перебігу НВК, 3 - XК); II група - 9 хворих, оперованих з приводу обструктивного раку, накладена асцендоколостома (у 2 - цекостома, у 7 - колостома в ділянці правого зги- ну товстої кишки); III група - 13 хворих, у яких сформована десцендоколостома 3 приводу обструктивного раку, непрохідності кишечнику.

Дослідження проведене згідно чинних в Україні нормативних документів. Матеріал (випорожнення) забирали стерильним тампоном 3 транспортним середовищем у контейнер, доставляли в мікробіологічну лабораторію протягом $1-2$ год для дослідження мікробіоценозу.

Виділені штами ентеробактерій ідентифікували на основі їх біонічної активності за допомогою CIП-I і CIП-II, ЕНTЕPО-тест 1 і 2 ("Lachema", Брно, Чехія). Вид мікроорганізму визначали на основі аналізу біохімічних властивостей за визначником Берджі.

\section{РЕЗУЛЬТАТИ \\ ТА ÏХ ОБГОВОРЕННЯ}

Проводили мікроскопію, хімічне і бактеріологічне дослідження калу. На підставі результатів досліджень виділені копрологічні синдроми. 
Синдром недостатності перетравлення в тонкій кишці: рідкий жовтий кал, лужна реакція, велика кількість м'язових волокон, нейтрального жиру, йодофільної мікрофлори, значна кількість жирних кислот, дуже високий вміст крохмалю та клітковини (у 4 пацієнтів).

Синдром прискореної евакуації 3 тонкої кишки: рідкі жовті або світло- коричневі випорожнення слабо-лужної реакції, значна кількість м'язових волокон, жирних кислот, сполучної тканини, дуже багато нейтрального жиру, крохмалю (у 3 пацієнтів). При вивченні копрограм після створення єюноколостоми за різними способами основну увагу звертали на вміст м'язових волокон, нейтрального жиру та жирних кислот, внутрішньо- та позаклітинного крохмалю (див. рисунок).

Після здійснення ілеостомії $\mathrm{pH}$ калу перевищував 5,5 в одного хворого, клітковину, крохмаль, нейтральний жир та жирні кислоти, м'язові
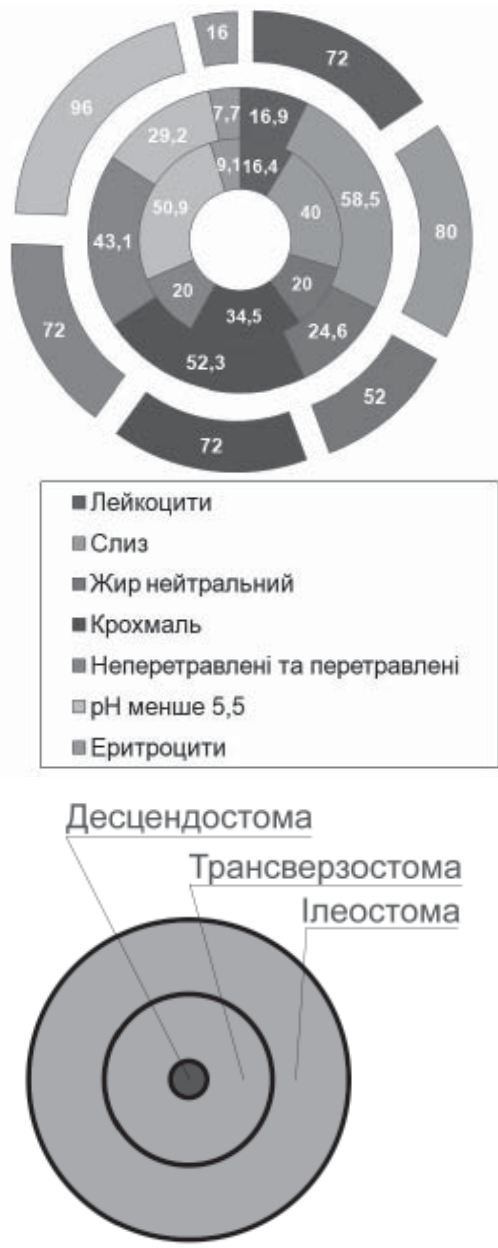

Копрограма пацієнтів, у яких сформовано стому після обструктивних операцій. волокна, слиз, лейкоцити спостерігали у значно більшій кількості, ніж у хворих, яким накладали колостому. М'язові волокна виявляли у $72 \%$ пацієнтів, жир - у 52\%, крохмаль - у $72 \%$. Подібні порушення спостерігали тільки у хворих після гастректомії і/або резекції шлунка за БільротII, коли з пасажу виключали дванадцятипалу кишку, синдром мальабсорбції пов'язаний 3 пригніченням зовнішньосекреторної функції підшлункової залози. Найменш вираженою така недостатність була у пацієнтів, яким формували десцендоколостому: м'язові волокна виявлені у 20\%, жир і жирні кислоти - у 20\%, крохмаль - у 34,5\%.

Абсорбція білка порушується меншою мірою, ніж абсорбція жирів. Протягом кількох місяців після операції спостерігали збільшення втрат азоту з калом, проте, позитивний азотистий баланс зберігався. До кінця року засвоення білка нормалізувалося, у віддаленому періоді було нормальним. Абсорбція вуглеводів після накладання стоми порушувалася незначною мірою, проте, внаслідок зменшення абсорбції жиру, а іноді і білка, пацієнти втрачали до 13\% енергетичної цінності добової дієти [1]. За наявності ілеостоми в ранньому післяопераційному періоді виникає проблема іiі дисфункції, особливо у пацієнтів при запальних захворюваннях товстої кишки (НВК, ХК). Поняття дисфункції стоми включає як метаболічні розлади, зумовлені пришвидшеним транзитом вмісту по кишечнику, відсутністю його проходження по частині тонкої та товстої кишки, дисбіотичні, так і параентеростомні ускладнення.

При НВК майже у 85\% пацієнтів відзначають порушення всмоктування, при ХК ступінь порушення значно більший, ці питання слід регулювати після операції [5]. Тому проблема зменшення та регуляції об'єму випорожнень і відновлення внутрішньокишкової мікрофлори у пацієнтів при запальних захворюваннях товстої кишки, що потребують виведення тонкої кишки на передню черевну стінку (ілеостома), у ранньому післяопераційному періоді є актуальною. Метаболічні розлади, що виникають в організмі через відсутність пасажу вмісту по товстій киш- ці, поглиблюють дисфункцію ілеостоми. Кількість таких пацієнтів в останні роки значно збільшилася як загалом, так і молодого віку (від 20 до 45 років). Через збільшення кількості хворих завдяки ранньому ретельному обстеженню частота виконання оперативних втручань буде неухильно збільшуватись. 3 огляду на тяжкий соматичний стан цих пацієнтів в момент госпіталізації, ураження життєво важливих органів та значний обсяг оперативного лікування, хірургічні втручання, як правило, здійснюють у два етапи.

Перший етап (у 40 - 60\% пацієнтів) передбачає усунення непрохідності кишечнику, зменшення тяжкості інтоксикації організму, виконання оперативного втручання 3 формуванням ілеостоми; другий - відновлення безперервності кишечнику. Тривалість функціонування стоми залежить від тяжкості домінуючого захворювання і становить від 2 до 6 міс. Важливе значення має бактеріологічне дослідження мікрофлори випорожнень для виявлення дисбактеріозу, що зумовлюе виникнення ентериту і в подальшому підтримує його хронічний перебіг. У хворих виявлене зменшення концентрації біфідо- і лактобактерій, збільшення рівня гемолітичних і лактозонегативних ешерихій, патогенного стафілокока, протея, анаеробних клостридій. Відновлення нормальної мікрофлори кишечнику $є$ досить показовим критерієм успішності лікування. За наявності ілеостоми з переважним ураженням тонкої кишки активність ентерокінази і лужної фосфатази (ферментів, що беруть участь у процесі всмоктування білка і жирних кислот) значно підвищується в усіх iіi частинах і у випорожненнях. Підвищення активності ферментів у тонкій кишці зумовлене компенсаторним збільшенням їх продукції, посиленням десквамації кишкового епітелію, що містить ці ферменти. Підвищення активності ферментів в калі зумовлене посиленням моторики кишечнику, порушенням процесів дезактивації ферментів в дистальних частинах кишечнику внаслідок активації мікрофлори. За даними бактеріологічного дослідження виділень з стоми у хворих перед виконанням реконструктивно-відновно- 
го втручання виявлені значні зміни складу мікрофлори кишечнику, що на тлі оперативного лікування можуть спричинити гнійно-септичні ускладнення. Це обгрунтовує необхідність розробки способів та проведення передопераційної підготовки 3 використанням місцевої та загальної антибіотикопрофілактики.

Практично в усіх пацієнтів діагностований анаеробний дисбаланс, переважно внаслідок збільшення концентрації клостридій та умовно патогенної мікрофлори. У пацієнтів за наявності трансверзостоми та десцендоколостоми виявлені C. difficile, збільшена кількість умовно патогенних мікроорганізмів. За результатами багатофакторного аналізу не встановлено статистично значущої залежності виявлених змін мікрофлори від статі і віку пацієнтів, обсягу і способу оперативного втручання, наявності пухлинного стенозу та інфільтрату (р
$<0,05)$. Доведено, що гнильні й патогенні мікроорганізми виробляють в кишечнику токсичні речовини, зокрема, ешерихії, клебсієли і клостридії - аміак, аміни, нітрозаміни, феноли, крезоли, індол, вторинні жовчні кислоти, аглікони; протей - аміак, аміни, індол $[1,6]$. Продукти метаболізму патогенних мікроорганізмів справляють токсичний вплив на організм людини. Так, аміак $є$ гепато- і нейротоксичним; аміни, феноли, крезоли, інол, скатол, вторинні жовчні кислоти - канцерогенними. У здорової людини концентрація цих токсинів низька.

Значне порушення мікробіоценозу кишечнику, притаманне хворим, яким накладено стому, спричиняє ендотоксемію, ii токсичний вплив на печінку проявляється стеатозом та стеатогепатитом. Це збільшує ризик виникнення стеатогепатиту у віддаленому періоді, що зумовлює порушення основних функ- цій печінки й інші метаболічні розлади. Гіперендотоксемія формується у хворих внаслідок порушення мікробіоценозу ТК, збільшує ризик виникнення захворювань органів панкреатодуоденальної зони та серцево-судинних ускладнень.

\section{ВИСНОВКИ}

1. Синдром мальабсорбціі найбільш виражений у хворих за наявності ілеостоми. В копрограмах м'язові волокна виявляли у $72 \%$, жир у $52 \%$, крохмаль - у $72 \%$ таких хворих; за наявності десцендоколостоми відповідно у 20, 20 і 34,5\%.

2. В усіх хворих, яким сформовано стому, діагностований дисбаланс мікрофлори 3 підвищенням рівня клостридій та умовно патогенних мікроорганізмів. У пацієнтів за наявності трансверзо- та десцендоколостоми виявлені C. difficile на тлі збільшення концентрації умовно патогенної мікрофлори.

\section{ЛITEPATYPA/REFERENCES}

1. Babak OYa. Syndrom dysbiotychnykh porushen mikroflory kyshechnyka: suchasnyi pohliad na problemu. Simeina medytsyna. 2006;2:4-6. [In Ukrainian].

2. Zhukov VI, Perepadja SV, Vinnik JuA, Zajceva OV. Prognosticheskoe znachenie serotonina $v$ diagnostike stadii zabolevanija i jeffektivnosti patogeneticheskogo lechenija kolorektalnogo raka. Problemi ekologiï ta medicini. 2009;13(3-4):20-2. [In Russian].

3. Vinnik JuA, Perepadja SV, Zhukov VI, Zajceva OV. Sostojanie obmena melatonina u bolnyh kolorektal'nym rakom i ego prognosticheskoe znachenie $v$ patogeneticheskom lechenii. Visnik problem biologiï i medicini. 2009;2:49-52. [In Russian].
4. Matarese L. Bacteria-induced disease with bacteria. Nutricition in clinical practice. 2012;(27):242-6.

5. Bayless T, Hanauer S. Advance therapy of inflammatory bowel disease: Ulcerative colitis. volume I. PMPH USA, 2011. $470 \mathrm{~s}$.

6. Banerjee B. Nutritional management of digestive disorders. Taylor and francis Group USA, LLC, 2011. 138 s. 